\title{
KEPATUHAN KOPERASI \\ DI KOTA SEMARANG TERHADAP STANDAR AKUNTANSI KEUANGANENTITAS TANPA AKUNTAN PUBLIK (SAK ETAP) TAHUN 2013
}

\author{
Warno $^{1}$
}

\begin{abstract}
Abstraksi
Koperasi merupakan lembaga yang menjalankan kegiatan usaha dan pelayanan yang sangat membantu dan dibutubkan oleh anggota koperasi khususnya dan masyarakat pada umumnya. Koperasi juga menerapkan pedoman standar akuntansi keuangan (PSAK). $S A K$ ETAP diterapkan untuk penyusunan laporan keuangan yang dimulai pada atau setelah 1 Januari 2011. Tujuan nya adalah untuk menyediakan informasi posisi keuangan, kinerja keuangan, dan laporan arus kas suatu entitas yang bermanfaat bagi sejumlah besar pengguna dalam pengambilan keputusan ekonomi oleh siapapun yang tidak dalam posisi dapat meminta laporan keuangan khusus untuk memenubi kebutuhan informasi tertentu

Berdasarkan hasil penelitian menunjukkan babwa koperasi dikota semarang sebanyak. 50 koperasi yang dipakai untuk sampel penelitian sebagian kecil sudah menerapkan $S A K$ ETAP, sedangkan sebagian besar menerapkan SAK ETAP tetapi belum keseluruban ketentuan, koperasi yang belum sama sekali menerapkan SAK ETAP tidak ada. Dari hasil tersebut maka perlu adanya tindakan dari pibak regulator untuk membenahi hal tersebut yaitu bertujuan agar selurub koperasi taat dengan $S A K E T A P$, adanya ketidak patuban dari koperasi bisa disebabkan berbagai hal.
\end{abstract}

Keyword : Kepatuhan, SAKETAP

\section{Pendahuluan}

Ada tiga pilar standar akuntansi keuangan yaitu :

a) Standar Akuntansi Keuangan (PSAK)

b) SAK ETAP

c) SAK Syariah

Awal mula dari standar akuntansi adalah pedoman standar akuntansi keuangan (PSAK) namun muncul standar yang lain dengan berbagai latar

${ }^{1}$ Dosen Tetap STIE Semarang

Volume V/Edisi 1/Mei 2014 
Kepatuhan Koperasi di Kota Semarang

belakang, PSAK yang mengadopsi IFRS terlalu kompleks untuk diterapkan oleh perusahaan kecil menengah di Indonesia, pada awalnya standar akuntansi keuangan entitas tanpa akuntan publik (SAK ETAP) mengikuti IFRS, namun IFRS masih terlalu kompleks untuk ukuran perusahaan menengah di Indonesia, sehingga SAK ETAP berbeda cukup signifikan dengan IFRS.

Dengan berkembangnya berbagai entitas yang menerapkan syariah dalam pengelolaanya maka muncul pula berbagai standar syariah yaitu standar akuntansi keuangan syariah (SAK Syariah) Koperasi merupakan lembaga yang menjalankan kegiatan usaha dan pelayanan yang sangat membantu dan dibutuhkan oleh anggota koperasi khususnya dan masyarakat pada umumnya. Koperasi, selain sebagai badan usaha sekaligus juga sebagai gerakan ekonomi rakyat yang berdasarkan asas kekeluargaan. Koperasi bertujuan untuk memajukan kesejahteraan para anggota koperasi khususnya dan masyarakat pada umumnya, oleh karena itu Koperasi mempunyai fungsi dan peran untuk membangun dan mengembangkan potensi dan kemampuan usaha para anggota koperasi dan masyarakat umum, untuk meningkatkan kesejahteraan ekonomi dan usahanya.

Usaha pemerintah dalam membangun dan mengembangkan koperasi sebagai badan usaha dan gerakan ekonomi rakyat adalah dengan mewujudkan koperasi yang dikelola secara professional dengan menerapkan prinsip keterbukaan, transparansi dan akuntabilitas yang dapat diakui, diterima dan dipercaya baik oleh anggotanya maupun masyarakat umum. Sehingga koperasi perlu menyelenggarakan akuntansi secara benar dan tertib. Penerapan akuntansi dan penyampaian laporan keuangan koperasi menunjukkan kekhususan koperasi dibandingkan dengan penerapan akuntansi dan laporan keuangan badan usaha yang lain. Dalam menyusun laporan keuangan, koperasi harus sesuai dengan Pedoman Umum Akuntansi Koperasi Indonesia, yang berisi praktek penerapan akuntansi koperasi yang mengacu pada laporan keuangan internasional (International Financial Reporting Standard atau IFRS). Sesuai dengan kebijakan Ikatan Akuntansi Indonesia dan Dewan Standar Akuntansi Keuangan, yang telah menerbitkan Pernyataan Pencabutan Standar Akuntansi Keuangan 8 (PPSAK 8) atas pencabutan Pernyataan Standar Akuntansi Keuangan 27 (PSAK 27) tentang Akuntansi Koperasi. 
Dengan dicabutnya PSAK 27, sejak tanggal 1 Januari 2011, Standar Akuntansi Keuangan Koperasi menggunakan kebijakan akuntansi yang baru yaitu Standar Akuntansi Keuangan Entitas Tanpa Akuntabilitas Publik (SAKETAP), yang digunakan untuk entitas tanpa akuntabilitas publik yaitu entitas yang tidak memiliki akuntabilitas publik signifikan dan menerbitkan laporan keuangan untuk tujuan umum (general purpose financial statement) bagi pengguna eksternal seperti pemilik yang tidak langsung dalam pengelolaan usaha, kreditur dan lembaga pemeringkat kredit. Koperasi termasuk dalam entitas tanpa akuntabilitas publik, sehingga koperasi harus memberlakukan akuntansi koperasi dengan SAK ETAP. Bersama dengan mulai diberlakukannya SAK ETAP pada badan usaha koperasi, maka pemerintah menerbitkan Peraturan Menteri Negara Koperasi dan Usaha Kecil Menengah No. 4 tahun 2012 tentang Pedoman Umum Akuntansi Koperasi. Pedoman tersebut menetapkan bentuk, isi penyajian dan pengungkapan laporan keuangan koperasi untuk kepentingan internal koperasi maupun pihak lain selaku pengguna laporan keuangan koperasi. Pedoman tersebut juga merupakan acuan yang harus dipatuhi oleh koperasi dan aparat dalam melakukan pembinaan dalam menyusun laporan keuangan.

SAK ETAP diterapkan untuk penyusunan laporan keuangan yang dimulai pada atau setelah 1 Januari 2011. Tujuan laporan keuangan adalah untuk menyediakan informasi posisi keuangan, kinerja keuangan, dan laporan arus kas suatu entitas yang bermanfaat bagi sejumlah besar pengguna dalam pengambilan keputusan ekonomi oleh siapapun yang tidak dalam posisi dapat meminta laporan keuangan khusus untuk memenuhi kebutuhan informasi tertentu. Dalam memenuhi tujuannya, laporan keuangan juga menunjukkan apa yang telah dilakukan manajemen (stewardship) atau pertanggunganjawaban manajemen atas sumber daya yang dipercayakan kepadanya (SAK ETAP paragraph 2.1). Penyajian informasi laporan keuangan koperasi harus memperhatikan ketentuan SAK ETAP yang merupakan karakteristik kualitatif informasi laporan keuangan, yaitu : dapat dipahami, relevan, materialitas, keandalan, substansi menggungguli bentuk, pertimbangan sehat, kelengkapan, dapat dibandingkan, tepat waktu, dan keseimbangan antara biaya dan manfaat.

Dalam laporan keuangan, tercatat semua transaksi yang terjadi pada koperasi selama satu periode, sehingga pemakai dapat mengetahui manfaat 
Kepatuhan Koperasi di Kota Semarang

yang diperoleh sebagai anggota koperasi selama satu periode dengan Selisih Hasil Usaha (SHU) yang diperoleh, sumber daya ekonomi yang dimiliki dan dapat pula diketahui kewajiban dan kekayaan bersihnya. Keterbatasan pengetahuan manajemen akan mengakibatkan kesulitan untuk menganalisis lingkungan usaha, ketidak mampuan dalam mengidentifikasikan peluangpeluang yang ada dalam lingkungan, sehingga pada akhirnya akan menemui kesulitan dalam menyusun perencanaan, khususnya perencanaan dalam keuangan atau laporan keuangan. Kurangnya tenaga trampil juga akan mengakibatkan tidak teraturnya sistem pembukuan. Dengan adanya aturan baru bagi koperasi, yaitu SAK ETAP, maka banyak koperasi yang belum menyusun laporan keuangan berdasarkan SAK ETAP secara benar atau bahkan mungkin tidak tahu atau tidak paham dengan adanya SAK ETAP. Untuk meningkatkan pengetahuan, kemampuan dan ketrampilan sumber daya manusia yang ada di koperasi, perlu diadakan pendidikan dan pelatihan serta pembinaan yang berkaitan dengan perkoperasian, misalnya pendidikan dan pelatihan tentang menyusun laporan keuangan berdasarkan SAK ETAP. Setelah mengikuti diklat, diharapkan penyusunan dan penyajian laporan keuangan berdasarkan SAK ETAP bisa dilakukan dan tidak mengalami kesulitan.

Koperasi di kota Semarang sampai saat ini berjumlah 1.057, dari jumlah tersebut 234 koperasi atau 22,16\% nya dinyatakan tidak aktif, dan hanya 647 koperasi atau 61,2\% yang mengadakan Rapat Anggota Tahunan (RAT) pada tahun 2011. Dengan adanya aturan baru yang mengharuskan setiap koperasi menggunakan SAK ETAP dalam membuat laporan keuangannya, apakah koperasi yang ada di kota Semarang tersebut sudah menerapkan SAK ETAP dalam pembuatan laporan keuangannya atau belum, maka perlu adanya penelitian yang lebih mendalam tentang penerapan SAK ETAP pada koperasi di kota Semarang, mengingat SAK ETAP juga belum lama diberlakukan. Maka penelitian ini mengambil judul : Kepatuhan Koperasi Di Kota Semarang Terhadap Standar Akuntansi Keuangan Entitas Tanpa Akuntan Publik (Sak Etap) Tahun 2013 


\section{Perumusan Masalah}

Dengan dicabutnya PSAK 27 dan diberlakukannya SAK ETAP sejak 1 Januari 2011, maka koperasi yang termasuk dalam entitas tanpa akuntabilitas publik, juga harus menggunakan SAK ETAP dalam penyajian dan pengungkapan laporan keuangannya. Dari latar belakang tersebut maka permasalahan dalam penelitian ini :

"Apakah koperasi yang ada di kota Semarang dalam penyajian dan pengungkapan laporan keuangannya sudah sesuai dengan SAK ETAP ? ”

\section{Tujuan Penelitian}

Untuk mengetahui apakah laporan keuangan yang dibuat oleh koperasi di kota Semarang sudah sesuai dengan SAK ETAP dan mengetahui kendalakendala yang dihadapi dalam penerapan SAK ETAP

\section{Manfaat Penelitian}

\section{Pemerintah}

Bagi pihak pemerintah sebagai masukan dalam rangka memperbaiki kinerja koperasi di kota Semarang, dimana kinerja koperasi dapat dilihat dari laporan keuangan yang dibuat, apakah sudah sesuai dengan aturan atau standar yang berlaku

2. Koperasi

Bagi koperasi di kota Semarang, penelitian ini berguna sebagai masukan terutama dalam membuat laporan keuangan sesuai SAK ETAP dan mencari solusi atau pemecahan masalah tentang kendala yang dihadapi koperasi dalam penerapan SAK ETAP.

\section{Landasan Teori}

1. Pengertian, Landasan, Asas dan Tujuan Koperasi

Berdasarkan Undang-Undang Republik Indonesia No. 17 tahun 2012 tentang Perkoperasian, Koperasi adalah badan hukum yang 
Kepatuhan Koperasi di Kota Semarang

didirikan oleh orang perseorangan atau badan hukum Koperasi dengan pemisahan kekayaan para anggotanya sebagai modal untuk menjalankan usaha, yang memenuhi aspirasi dan kebutuhan bersama di bidang ekonomi, sosial dan budaya sesuai dengan nilai dan prinsip Koperasi. Landasan Koperasi adalah Pancasila dan Undang-Undang Dasar Negara Republik Indonesia 1945, dan berdasar atas asas kekeluargaan. Sedangkan tujuan koperasi adalah meningkatkan kesejahteraan Anggota pada khususnya dan masyarakat pada umumnya, sekaligus sebagai bagian yang tidak terpisahkan dari tatanan perekonomian nasional yang demokratis dan berkeadilan.

Nilai yang mendasari kegiatan Koperasi adalah kekeluargaan, menolong diri sendiri, bertanggung jawab, demokrasi, persamaan, berkeadilan dan kemandirian. Sedangkan nilai yang diyakini Anggota Koperasi adalah kejujuran, keterbukaan, tanggung jawab dan kepedulian terhadap orang lain. Prinsip Koperasi menjadi sumber inspirasi dan menjiwai secara keseluruhan organisasi dan kegiatan usaha koperasi sesuai dengan maksud dan tujuan pendiriannya, serta merupakan ciri khas koperasi yang membedakan koperasi dengan badan usaha lain. Adapun prinsip Koperasi meliputi :

a. Keanggotaan Koperasi bersifat sukarela dan terbuka

b. Pengawasan oleh Anggota diselenggarakan secara demokratis

c. Anggota berpartisipasi aktif dalam kegiatan ekonomi Koperasi

d. Koperasi merupakan badan usaha swadaya yang otonom dan independen

2. Karakteristik Koperasi

Karakteristik utama koperasi adalah posisi anggota koperasi sebagai pemilik sekaligus sebagai pengguna jasa koperasi. Sedangkan karakteristik koperasi yang lain adalah sebagai berikut:

a. Koperasi dibentuk oleh anggota atas dasar ekonomi yang sama

b. Koperasi didirikan dan dikembangkan berlandasakan nilai-nilai kemandirian, kesetiakawanan, keadilan, persamaan dan demokrasi, tanggung jawab sosial serta kepedulian terhadap orang lain 
c. Koperasi didirikan, diatur, dikelola, diawasi serta dimanfaatkan oleh anggotanya

d. Tugas pokok koperasi adalah melayani kebutuhan ekonomi anggotanya dalam rangka memajukan kesejahteraan anggota

e. Jika terdapat kelebihan kemampuan pelayanan koperasi kepada anggotanya maka kelebihan kemampuan pelayanan tersebut dapat digunakan untuk memenuhi kebutuhan msyarakat sekitarnya

3. Jenis Koperasi

Jenis Koperasi didasarkan pada kesamaan kegiatan usaha dan atau kepentingan ekonomi Anggota. Adapun jenis-jenis Koperasi terdiri dari : a. Koperasi Konsumen.

Koperasi konsumen menyelenggarakan kegiatan usaha pelayanan dibidang penyediaan barang kebutuhan Anggota dan nonAnggota

b. Koperasi Produsen

Koperasi produsen menyelenggarakan kegiatan usaha pelayanan dibidang pengdaan sarana produksi dan pemasaran produksi yang dihasilkan Anggota dan non-Anggota

c. Koperasi Jasa

Koperasi jasa menyelenggarakan kegiatan usaha pelayanan jasa non-simpan pinjam yang diperlukan oleh Anggota dan non-Anggota

d. Koperasi Simpan Pinjam

Koperasi Simpan Pinjam menjalankan usaha simpan pinjam sebagai satu-satunya usaha yang melayani Anggota. Kegiatan koperasi Simpan Pinjam adalah menghimpun dana dari anggota; memberikan pinjaman kepada anggota dan menempatkan dana pada koperasi simpan pinjam sekundernya.

4. Standar Akuntansi Keuangan Entitas Tanpa Akuntabilitas Publik (SAK ETAP)

1. Ruang Lingkup SAK ETAP

Sesuai dengan kebijakan Dewan Standar Akuntansi Keuangan dan Ikatan Akuntan Indonesia, yang pada tanggal 8 April 2011 telah 
Kepatuhan Koperasi di Kota Semarang

menerbitkan Pernyataan Pencabutan Standar Akuntansi Keuangan 8 (PPSK 8) atas pencabutan Pernyataan Standar Akuntansi Keuangan 27 (PSAK 27) tentang Akuntansi Koperasi, maka system akuntansi perkoperasian mulai disesuaikan dengan laporan keuangan IFRS. Standar Akuntansi keuangan yang mengacu pada IFRS dikelompokkan menjadi 2, yaitu SAK ETAP dan SAK Umum. Karena koperasi termasuk dalam entitas tanpa akuntabilitas publik, maka memberlakukan akuntansi koperasi dengan SAK ETAP. Untuk penyusunan laporan keuangan berdasarkan SAK ETAP dimulai pada atau setelah 1 Januari 2011.

SAK ETAP dimaksudkan untuk digunakan oleh entitas tanpa akuntabilitas publik. Entitas tanpa akuntabilitas publik adalah entitas yang :

1. Entitas yang tidak memiliki akuntabilitas publik yang signifikan dan

2. Menerbitkan laporan keuangan untuk tujuan umum (general purpose financial statement) bagi pengguna eksternal. Misalnya pengguna eksternal, yaitu pemilik yang tidak terlibat langsung dalam pengelolaan usaha, kreditur dan lembaga pemeringkat kredit.

3. Tidak tercatat di pasar modal

4. Tidak sedang dalam proses untuk pengajuan pernyataan pendaftaran pada otoritas pasar modal atau regulator lain untuk tujuan penerbitan efek di pasar modal

5. Tidak menguasai aset dalam kapasitas sebagai fidusia untuk sekelompok besar masyarakat, seperti bank, entitas asuransi, pialang dan atau pedagang efek, dana pensiun, reka dana dan bank investasi.

2. Manfaat SAK ETAP

1. Entitas yang dimaksud dapat menyusun laporan keuangannya sendiri.

2. Dapat diaudit dan mendapatkan opini audit

3. Dapat menggunakan laporan keuangannya untuk mendapatkan dana (dari Bank misalnya) untuk pengembangan usaha

3. Standar akuntansi keuangan entitas tanpa akuntan publik (SAK ETAP) 


\section{Pemberian dan Penyaluran Kredit}

a) Bunga diakui secara akrual

b) Provisi yang diterima harus diamortisasi selama masa kredit secara garis lurus diakui sebagai bagian pendapatan bunga ( menambah)

c) Biaya transaksi yang timbul dalam rangka pemberian kredit (yang ditanggung koperasi) diamortioasi secara garis lurus selama masa kredit, dan diakui sebagai bagian dari pendapatan bunga (pengurang)

d) Penyajian dalam neraca sebesar pokok kredit/baki debet dikurangi provisi serta ditambah biaya transaksi yang belum diamortisasi

\section{Pembentukan cadangan kerugian piutang yang tak tertagih.}

a) Pada saat penyusunan Laporan Keuangan Nominatif kredit harus diklasifikasikan Lancar,Kurang Lancar,Diragukan dan Macet.

b) Koperasi harus membentuk penyisihan kerugian kredit dengan memperhitungkan nilai agunan

c) Penyajian Penyisihan Kerugian disajikan sebagai pos pengurang dari kredit yang diberikan.

\section{Penghapusbukuan Kredit}

a) Hapus buku hanya dilakukan jika kredit dalam kategori macet dan telah dibentuk PPAP secara penuh

b) Pelaksanaan penghapusbukuan kredit dapat dilaksanakan bersamaan dengan penghapusan hak tagih

c) Kredit yang tagihannya telah dihapus buku bukan dalam rangka hapus tagih dicatat extracomptable sedangkan hapus buku dalam rangka hapus tagih tidak dicatat dalam extracomtable

d) Setoran yang diterima dari debitur atas kredit yang telah dihapus buku/tagih diakui sebagai pendapatan usaha lainnya

\section{Kredit yang dijamin Asuransi}

Jika kredit yang dijamin asuransi mengalami default, maka pihak asuransi akan mengganti kerugian Koperasi sesuai dengan perjanjian 
Kepatuban Koperasi di Kota Semarang

\section{Restrukturisasi Kredit}

1. Setiap pelaksanaan restrukturisasi kredit harus dibuat perjanjian

2. Restrukturisasi kredit dilakukan jika ada keyakinan bahwa debitur masih memiliki kemampuan untuk memenuhi kewajibannya setelah direstrukturisasi.

3. Restrukturisasi kredit tidak serta merta akan mengakibatkan peningkatan kualitas kredit.

4. Restrukturisasi kredit dilakukan dengan modifikasi :
a. Penurunan suku bunga
b. Perpanjangan jangka waktu kredit
c. Pengurangan tunggakan bunga
d. Pengurangan jumlah pokok kredit
e. Penambahan fasilitas kredit baru

5. Pembayaran kas masa depan harus diukur sebesar nilai tunai dengan menggunakan bunga kontraktual

\section{Agunan yang diambil alih ( AYDA )}

Agunan kredit yang diserahkan kepada koperasi dapat dibagi :

\section{Merupakan penyelesaian kredit :}

a. Perjanjian kredit antara koperasi dengan debitur selesai

b. Koperasi tak berhak atas pembayaran jika nilai AYDA lebih rendah dibandingkan dengan nilai kredit dan atau Koperasi tidak berkewajiban melakuka pembayaran jika AYDA lebih tinggi dibandingkan dengan nilai kredit

\section{Proses penyelesaian kredit :}

a. Perjanjian kredit antara koperasi dengan debitur tidak berakhir ketika agunan dikuasai koperasi

b. Koperasi berhak atas pembayaran jika nilai AYDA lebih rendah dibandingkan nilai kredit dan atau koperasi wajib membayar kepada debitur jika AYDA lebih tinggi dibandingkan nilai kredit 


\section{Penyajian dalam neraca}

Penyajian dalam neraca masuk dalam kelompok aset lain-lain

\section{SAK ETAP TENTANG ASET TETAP DAN INVENTARIS}

\section{Dasar pengaturan SAK ETAP bab 15,17 dan 22}

Biaya perolehan asset tetap terdiri : harga beli, termasuk bea balik nama dan pajak, penyiapandan biaya lain sampai asset tersebut siap digunakan. Perolehan asset tetap dengan cara :

1. Pembelian, dicatat sesuai dengan harga perolehannya.

2. Menerima sumbangan, diakui sebagai bagian tambahan modal disetor

3. Diperoleh dari undian berhadiah diakui sebagai pendapatan non operasional

4. Pertukaran asset tetap :

a) Transaksi pertukaran tidak memiliki substansi komersial, maka biaya perolehan diukur dengan jumlah tercatat dari asset yang diserahkan.

b) Transaksi pertukaran memiliki subtansi komersial, maka selisih antara nilai wajar asset yang dipertukarkan diakui sebagai pendapatan/beban

5. Sewa Pembiayaan (finance lease), dengan syarat:

a) Perjanjian sewa mengalihkan kepemilikan asset kepada koperasi pada akhir masa sewa

b) Koperasi mempunyai opsi untuk membeli asset

c) Masa sewa sama atau lebih dari $75 \%$ umur ekonomis asset

d) Jumlah pembayaran sewa minimum sama atau lebih dari $90 \%$ nilai wajar asset yang disewa.

e) Biaya perolehan asset tetap yang diperoleh melalui sewa adalah nilai tunai dari seluruh pembayaran sewa ditambah nilai residu yang harus dibayar pada akhir masa sewa 
Kepatuhan Koperasi di Kota Semarang

6. Penyajian:

Aset tetap disajikan berdasarkan nilai perolehan dikurangi akumulasi, khusus untuk asset berasal dari sewa pembiayaan disajikan tersendiri dalam pos aset tetap.

\section{Sewa Pembiayaan}

Koperasi Maju Jaya mengadakan sewa pembiayaan dengan Adira Finance dengan ketentuan untuk Kendaraan Rush :

a) Pada akhir masa sewa pembiayaan kendaraan Rush tersebut akan menjadi milik koperasi.

b) Kendaraan tersebut memiliki usia ekonomis 4 tahun dan akan disewa untuk jangka waktu 4 tahun, mulai 1 Januari 2007, dengan biaya sewa Rp 158.500.000. Koperasi harus mengasur tiap tahun Rp 50.000.000 (angsuran pokok dan bunga)

c) Akhir masa sewa nilai residu kendaraan Rp 15.000 .000

d) Tingkat bunga $10 \%$ pertahun

\section{PENURUNAN NILAI ASSET TETAP}

Penurunan nilai aset tetap diakui sebagai kerugian periode yang bersangkutan

\section{SAK ETAP ASET TIDAK BERWUJUD}

\section{Dasar Pengaturan Sak Etap bab 16}

1. Merupakan asset non moneter yang dapat diidentifikasi dan tidak mempunyai wujud fisik

a. Muncul karena hak kontraktual atau hak hukum lainnya

b. Kemampuannya untuk menjadi terpisah atau terbagi dari Koperasi dan dijual,dialihkan,dilesensikan ,disewakan atau ditukarkan melalui kontrak terkait aset atau kewajiban 
2. Umur manfaat asset tidak berwujud yang tidak dapat diestimasi 10 tahun, sedangkan bagi asset tak berwujud yang berasal dari hak kontraktual/hukum lainnya maksimal sama dengan periode hak kontraktual/hak hukum lainnya.

3. Penyajian dalam neraca adalah sebesar harga perolehan dikurangi akumulasi amortisasi.

\section{KEWAJIBAN SEGERA}

\section{Dasar pengaturan Sak Etap paragraph 2.35}

1. Kewajiban segera berasal dari aktivitas yang mendukung kegiatan operasional dan diakui pada saat telah jatuh tempo.

2. Penyajian dalam neraca sebesar jumlah yang menjadi kewajiban.

3. Kewajiban segera antara lain terdiri :
a. Saldo tabungan yang sudah ditutup
b. Tabungan berjangka (lebih dari satu tahun )/deposito yang sudah jatuh tempo tapi belum diambil oleh pemiliknya.
c. Bunga tabungan/deposito yang sudah jatuh tempo namun belum diambil oleh pemiliknya
d. Selisih lebih hasil penjualan agunan yang menjadi hak debitur
e. Dana SHU yang telah ditetapkan tetapi belum dibagi.
f. Bunga yang dibebankan (akrual) dan belum jatuh tempo
g. Pendapatan diterima dimuka

\section{Dasar pengaturan Sak Etap bab 24 tentang Pajak Penghasilan}

1. Utang pajak merupakan selisih kurang atas kewajiban pajak penghasilan setelah memperhitungkan angsuran pajak.

2. Utang pajak diakui sebesar jumlah yang harus disetor ke kas Negara 
Kepatuban Koperasi di Kota Semarang

\section{PINJAMAN YANG DITERIMA}

\section{Dasar pengaturan Sak Etap paragraph 2.35}

1. Pinjaman yang diterima dapat berasal dari Bank Umum, atau dari Koperasi lain, ( bantuan likuiditas dari pemerintah )

2. Pinjaman yang diterima tidak termasuk:

a. Pinjaman subrdinasi

b. Setoran dari bank lain (koperasi lain ) dalam kredit sindikasi (pembiayaan bersama )

c. Dana yang diterima dalam rangka penerusan kredit (channeling)

4. Laporan Keuangan Berdasarkan SAK ETAP

Laporan Keuangan yang sesuai SAK ETAP berisi :

a. Neraca, laporan keuangan yang menggambarkan tentang kondisi keuangan pada suatu periode. Komponen neraca adalah:

1. Aset, yaitu kekayaan yang dimiliki dan dikelola koperasi untuk menjalankan operational usaha. Aset juga merupakan sumber daya yang dikuasai kopersi sebagai akibat dari peristiwa masa lalu dan dari mana manfaat ekonomi di masa depan diharapkan akan diperoleh koperasi. Aset dapat diperoleh dari sumbangan, yang tidak terikat penggunaannya, diakui sebagai aset tetap. Komponen aset adalah aset lancar dan aset tidak lancar.

2. Kewajiban, merupakan pengorbanan ekonomis yang harus dilakukan oleh koperasi di masa yang akan datang dalam bentuk penyerahan aset atau pemberian jasa, yang disebabkan oleh tindakan atau transaksi pada masa sebelumnya. Kewajiban juga merupakan tanggungjawab koperasi saat ini, yang timbul dari peristiwa masa lalu yang penyelesaiannya diperkirakan akan kembutuhkan sumber daya ekonomi. Komponen Kewajiban adalah kewajiban jangka pendek dan kewajiban jangka panjang.

3. Ekuitas, adalah modal yang mempunyai ciri : berasal dari anggota dan atau dari sumber lain dalam koperasi, seperti 
cadangan, SHU tahun berjalan, dan dari luar koperasi seperti hibah. Komponen ekuitas adalah Simpanan Pokok, Simpanan Wajib, Hibah atau Modal Sumbangan, SHU tahun berjalan dan Cadangan.

b. Perhitungan Hasil Usaha

Perhitungan Hasil Usaha adalah laporan yang menggambarkan hasil usaha koperasi dalam satu periode akuntansi. Komponen Perhitungan Hasil Usaha adalah Pelayanan anggota, Pendapatan dari non anggota, Sisa Hasil Usaha Kotor, Beban Operasional, Pendapatan dan atau beban lainnya, Beban pajak, Sisa Hasil Usaha Setelah Pajak.

c. Catatan Atas laporan Keuangan

Catatan atas laporan keuangan koperasi harus memuat pengungkapan kebijakan koperasi yang mengakibatkan perubahan perlakuan akuntansi dan pengungkapan informasi lainnya. Perlakuan akuntansi yang harus diinformasikan antara lain adalah kebijakan akuntansi tentang aset tetap, penilaian persediaan, piutang dan sebagainya; Pos-pos yang nilainya material harus dirinci dan dijelaskan dalam catatan laporan keuangan; Catatan atas laporan keuangan koperasi harus jelas dan nyata, memuat informasi lain seperti : kegiatan pelayanan utama koperasi kepada anggota, kegiatan bisnis koperasi dengan non anggota yang ditargetkan dan yang sudah dilaksanakan, aktivitas koperasi untuk mempromosikan ekonomi dan pengembangan kemampuan sumberdaya anggota melalui pendidikan dan pelatihan.

\section{d. Laporan Perubahan Ekuitas (Modal)}

Laporan perubahan ekuitas bertujuan menyajikan laba atau rugi koperasi untuk satu periode, pos pendapatan dan beban yang diakui secara langsung dalam ekuitas untuk periode tersebut, pengaruh kebijakan akuntansi dan koreksi kesalahan yang diakui dalam periode tersebut. Komponen Laporan Perubahan Ekuitas 
Kepatuhan Koperasi di Kota Semarang

menunjukkan perubahan dari simpanan pokok, simpanan wajib, hibah, cadangan, SHU yang tidak dibagikan, pada periode akuntansi.

e. Laporan Arus Kas

Laporan arus kas menyediakan informasi tentang uang tunai dan setara tunai dalam satu entitas untuk periode yang dilaporkan dalam komponen terpisah. Arus kas adalah arus kas masuk dan arus kas keluar uang tunai atau setara tunai. Komponen Arus kas adalah aktivitas operasi, aktivitas investasi dan aktivitas pendanaan.

Kerangka Pemikiran dan Hipotesis

Koperasi termasuk dalam entitas tanpa akuntabilitas public, sehingga koperasi harus memberlakukan akuntansi koperasi dengan SAK ETAP. Bersama dengan mulai diberlakukannya SAK ETAP pada badan usaha koperasi, maka pemerintah menerbitkan Peraturan Menteri Negara Koperasi dan Usaha Kecil Menengah No. 4 tahun 2012 tentang Pedoman Umum Akuntansi Koperasi. Pedoman tersebut menetapkan bentuk, isi penyajian dan pengungkapan laporan keuangan koperasi untuk kepentingan internal koperasi maupun pihak lain selaku pengguna laporan keuangan koperasi. Pedoman tersebut juga merupakan acuan yang harus dipatuhi oleh koperasi dan aparat dalam melakukan pembinaan dalam menyusun laporan keuangan.

Ada beberapa perbedaaan akuntansi berdasar SAK ETAP dan akuntansi berdasarkan SAK UMUM, hal itu bisa menyebabkan kesulitan bagi koperasi mengaplikasikanya dalam penyusunan laporan keuangan. Selain itu juga diperlukan kesiapan dan pemahaman dari sumber daya manusia (karyawan) koperasi untuk mempraktekkan aturan tersebut dalam penyusunan laporan keuangan. Adapun kerangka pemikiran penelitian ini dapat digambarkn sebagai berikut :

\begin{tabular}{|l|l}
\hline SAK ETAP & APLIKASI SAK ETAP $(\mathrm{Y})$ \\
\cline { 2 - 3 } & \\
\hline
\end{tabular}


Hipotesis merupakan simpulan sementara yang harus dilakukan dalam pengujian kebenaran. Berdasarkan kerangka pemikiran penelitian dapat dibuat hipotesis alternatif sebagai berikut :

$\mathrm{H}_{1}$ : Diduga koperasi patuh terhadap SAK ETAP

\section{Metodologi Penelitian}

\section{Jenis Penelitian}

Penelitian ini merupakan penelitian Case study khusus mengenai konsistensi penerapan SAK ETAP pada koperasi di kota Semarang tahun 2013.

\section{Populasi dan Sampel}

Populasi dalam penelitian ini adalah seluruh koperasi yang terdaftar di Dinas Koperasi Kota Semarang. Sedangkan yang akan dijadikan sampel adalah koperasi simpan pinjam dan koperasi serba usaha. Mengingat keterbatasan tenaga dan biaya yang ada maka jumlah sampel dibatasai hanya 50 koperasi. Sampel ditentukan secara acak (random)

\section{Jenis, sumber dan metode pengumpulan data}

Data yang digunakan dalam penelitian ini adalah data primer dan data sekunder. Data primer adalah data yang diperoleh langsung dari sumbernya, dan dalam penelitian ini diperoleh dari responden, yaitu para Manajer Koperasi, Manajer keuangan dan Kepala Bagian Akuntansi. Data primer tersebut diperoleh melalui kuesioner yang atau daftar pertanyaan kepada para responden berkaitan dengan aturan SAK ETAP.

Sedangkan data sekunder adalah data yang diperoleh tidak lansung dari sumbernya atau objek penelitian. Data sekunder ini diperoleh dengan metode dokumentasi, dan dalam penelitian ini berupa 
Kepatuban Koperasi di Kota Semarang

laporan keuangan dalam Rapat Anggota Tahunan (RAT) koperasi yang menjadi objek penelitian.

\section{Variabel penelitian}

Sampel yang digunakan dalam penelitian ini dipilih secara purposive sampling, sehingga sampel yang digunakan dalam penelitian ini merupakan representasi dari populasi sampel yang ada serta sesuai dengan tujuan dari penelitian. Proses seleksi sampel berdasarkan kriteria yang telah ditetapkan berikut ini :

1. Sampel penelitian terdaftar sebagai koperasi pada Dekopenda kota semarang tahun 2013

2. Koperasi yang telah menerbitkan dan mempublikasikan laporan selama periode pengamatan tahun 2013

Dari kriteria tersebut maka semua koperasi yang terdaftar di Dekopinda Kota Semarang peneliti ambil sebagai sampel yaitu 50 .

Variabel dalam penelitian ini adalah kepatuhan koperasi terhadap SAK ETAP, data penelitian diperoleh dengan melihat laporan keuangan yang sudah dibuat oleh koperasi dikota semarang tahun 2013.

\section{Model Analisis}

a. Uji Normalitas

Uji normalitas bertujuan untuk menguji apakah dalam model regresi variabel pengganggu atau residual memiliki distribusi normal, untuk melihat normalitas reesidual adalah dengan melihat grafik histogram yang membandingkan antara data observasi dengan distribusi yang mendekati distribusi normal.

Dari gambar p-p plot dan histogram penyebaran data (titik) pada sumbu diagonal dari grafik atau dengan melihat histogram dari residualnya. Dasar pengambilan keputusan:

1) Data menyebar disekitar garis diagonal dan mengikuti arah garis diagonal atau grafik histogramnya menunjukkan pola 
distribusi normal, maka model regresi memenuhi asumsi normalitas

2) Data tidak menyebar jauh dari diagonal dan/ tidak mengikuti arah garis diagonal atau grafik histogram tidak menunjukkan pola distribusi normal, maka model regresi tidak memenuhi asumsi normalitas.

b. Analisis Statistik Deskriptif

Statistik deskriptif memberikan gambaran atau deskripsi suatu data yang dilihat dari nilai rata-rata (mean), standar deviasi, varian, maksimum, minimum, sum, range, kurtosis dan skewness (kemencengan distribusi). Analisis deskriptif sangat membantu dalam meringkas perbandingan beberapa variabel data skala dalam satu tabel dan dapat digunakan untuk melakukan pengamatan outlier data. Selain itu bisa dipakai untuk mengambil kesimpulan dari data yang diolah.

\section{Pembahasan}

Tabel 1

Statistik Deskriptif

\begin{tabular}{|l|l|l|l|l|l|l|l|l|l|l|l|l|}
\hline & \multicolumn{1}{|c|}{$\mathrm{N}$} & Range & $\begin{array}{c}\text { Minimu } \\
\mathrm{m}\end{array}$ & $\begin{array}{c}\text { Maximu } \\
\mathrm{m}\end{array}$ & \multicolumn{2}{|c|}{ Mean } & $\begin{array}{c}\text { Std. } \\
\text { Deviatio } \\
\mathrm{n}\end{array}$ & Variance & \multicolumn{2}{|c|}{ Skewness } & \multicolumn{2}{|c|}{ Kurtosis } \\
\cline { 2 - 11 } & Statistic & Statistic & Statistic & Statistic & Statistic & $\begin{array}{c}\text { Std. } \\
\text { Error }\end{array}$ & Statistic & Statistic & $\begin{array}{c}\text { Statisti } \\
\mathrm{c}\end{array}$ & $\begin{array}{c}\text { Std. } \\
\text { Error }\end{array}$ & $\begin{array}{c}\text { Statisti } \\
\mathrm{c}\end{array}$ & $\begin{array}{c}\text { Std. } \\
\text { Error }\end{array}$ \\
\hline $\begin{array}{l}\text { K } \\
\begin{array}{l}\text { Valid N } \\
\text { (listwise) }\end{array}\end{array}$ & 50 & 1.00 & 2.00 & 3.00 & 2.3000 & .06547 & .46291 & .214 & .900 & .337 & -1.241 & .662 \\
\hline
\end{tabular}

Sumber: Data Sekunder yang diolah (2013)

Berdasarkan Tabel 1 menunjukkan jumlah sampel (N) ada 50 koperasi serta menggambarkan variabel yang diteliti yitu kepatuhan koperasi terhadap SAK ETAP. Untuk pertanyaan apakah koperasi sudah mematuhi SAK ETAP, 
Kepatuhan Koperasi di Kota Semarang

jawaban pertama yaitu koperasi belum menerapkan SAK ETAP memiliki nilai minimum sebesar 2 nilai maksimum sebesar 3, nilai rata-rata (mean) sebesar 2,3, serta nilai standar deviasi sebesar 0,46 . Kondisi tersebut menunjukkan bahwa koperasi di kota semarang yang belum mematuhi SAK ETAP adalah tidak ada, sedangkan untuk nilai standar deviasi yang lebih kecil dari nilai rat-rata (mean) menunjukkan bahwa rata-rata koperasi yang ada didekopinda kota semarang hampir sama tingkat kepatuhanya.

Untuk jawaban kedua yaitu koperasi menerapakan sebagaian SAK ETAP memiliki nilai minimum sebesar 2 nilai maksimum sebesar 3, nilai ratarata (mean) sebesar 2,3, serta nilai standar deviasi sebesar 0,46. Kondisi tersebut menunjukkan bahwa koperasi di kota semarang yang mematuhi sebagian ketentuan SAK ETAP adalah cukup banyak, sedangkan untuk nilai standar deviasi yang lebih kecil dari nilai rat-rata (mean) menunjukkan bahwa rata-rata koperasi yang ada didekopinda kota semarang hampir sama tingkat kepatuhanya.

Untuk jawaban ketiga yaitu koperasi sudah menerapkan SAK ETAP memiliki nilai minimum sebesar 2 nilai maksimum sebesar 3, nilai rata-rata (mean) sebesar 2,3, serta nilai standar deviasi sebesar 0,46. Kondisi tersebut menunjukkan bahwa koperasi di kota semarang yang mematuhi SAK ETAP adalah belum banyak, sedangkan untuk nilai standar deviasi yang lebih kecil dari nilai rat-rata (mean) menunjukkan bahwa rata-rata koperasi yang ada didekopinda kota semarang hampir sama tingkat kepatuhanya.

Sesuai pernyataan stándar akuntansi keuangan (PSAK) No. 27 tahun 1998 laporan keuangan koperasi dan direvisi mulai januari tahunh 2011 menerapkan SAK ETAP, maka koperasi harus menyajikan laporan :

1. Neraca

2. Perhitungan hasil usaha

3. Laporan arus kas

4. Laporan promosi ekonomi anggota

5. Catatan atas laporan keuangan

Dari sampel yang dipilih dari seluruh koperasi yang ada di kota Semarang sebanyak 50 koperasi menunjukkan dari kelima laporan keuangan tersebut untuk : Neraca, perhitungan hasil usaha, semua sudah membuat 
namun untuk : laporan arus kas, laporan promosi ekonomi anggota dan catatan laporan keuangan berbeda-beda ada yang membuat dan ada pula yang tidak membuat.

Selain ketentuan laporan keuangan juga ada berbagai ketentuan lain yang harus dipatuhi yaitu meliputi beberapa kebijakan akuntansi contohnya :

1. Kas

2. Piutang

3. Aktiva tetap

4. Utang

5. Ekuitas

6. Biaya

7. Pendapatan

Dari beberapa kebijakan tersebut koperasi belum semuanya mematuhi ketentuan dalam SAK ETAP

Berdasarkan hasil penelitian koperasi yang patuh dan tidak patuh lebih banyak yang tidaka patuh walaupun ketidakpatuhan dari koperasi tersebut adalah belum mampu memenuhi ketentuan secara keseluruhan. Mulai tahun 2011 SAK ETAP diwajibkan diaplikasikan oleh seluruh koperasi di Indonesia.

Adanya ketentuan yang harus dipatuhi oleh koperasi namun ada juga yang harus dicermati yaitu ada dua hal yang pertama adalah adakah hukuman bagi yang tidak mematuhi dan adakah sosialisasi, pendidikan, pelatihan bagi koperasi, apabila kedua hal tersbut tidak ada maka tentunya koperasi jika tidak patuh itu normal karena mungkin mereka belum mampu mempraktekkan aturan tersebut atau karena koperasi tidak mau susah-susah mengganti dan merekapun tidak diberikan hukuman karena alasan tersebut.

Perlu penelitian lebih lanjut mengenai bagaimana pengetahuan, pemahaman dan kemampuan dari pengelola koperasi dalam mengaplikasikan SAK ETAP, selain itu juga perlu penelitian lebih lanjut mengenai bagaimana dari pihak pemerintah melalui Kementrian Koperasi dan UKM dalam memberikan sosialisasi dan Diklat bagi koperasi sehingga mampu untuk melaksanakan aturan tersebut, dari sisi hukum juga harus diteliti apakah apabila 
Kepatuban Koperasi di Kota Semarang

tidak mematuhi SAK ETAP koperasi akan diberikan sangsi yang berat atau malah tidak ada sehinggal pelaksanaan dari aturan tersebut akan sulit.

\section{Kesimpulan}

Berdasarkan hasil penelitian menunjukkan bahwa koperasi dikota semarang sebanyak 50 koperasi yang dipakai untuk sampel penelitian sebagian kecil sudah menerapkan SAK ETAP, sedangkan sebagian besar menerapkan SAK ETAP tetapi belum keseluruhan ketentuan, koperasi yang belum sama sekali menerapkan SAK ETAP tidak ada.

Dari hasil tersebut maka perlu adanya tindakan dari pihak regulator untuk membenahi hal tersebut yaitu bertujuan agar seluruh koperasi taat dengan SAK ETAP, adanya ketidak patuhan dari koperasi bisa disebabkan berbagai hal misalkan :

a. Belum adanya sosialisasi yang baik sehingga ada koperasi belum mengetahuinya

b. Belum adanya pelatihan kepada koperasi, karena ada aturan tetapi tidak ada upaya agar bisa mampu mengaplikasikan aturan tersebut tentunya tidak akan berhail.

c. Tidak adanya sangsi yang berat bagi koperasi yang tidak mematuhi ketentuan tersebut. 


\section{DAFTAR PUSTKA}

Adenk Sudarwanto, Akuntansi Koperasi,Pendekatan praktis penyusunan Laporan Keuangan, Graha Ilmu Yogyakarta 2013

Arikunto, Suharsimi, Prosedur Penelitian Suatu Pendekatan Praktek, Jakarta: Rineka Cipta, 1998

Ayu Zuhroida, 26 April 2012, Aspek SDM dalam Pengelolaan Koperasi,

Febriani, 7 Appril 2013, Manajemen Sumber Daya Manusia Koperasi,

Gitosudarmo, Indriyo dan I Nyoman Sudita, Perilaku Keorganisasian, Edisi Pertama, (Yogyakarta: BPFE JOGJA, 2000), Hlm. 240.

Halim, Abdul, Analisis Investasi, (Jakarta: Salemba Empat, 2005)

IAI, 2009, SAK-ETAP, Jakarta

IAI, 23-10-2012, SAK Entitas Tanpa Akuntabilitas Publik (ETAP),

Kementrian Koperasi dan UKM RI, 29 Agustus 2012, Koperasi Didorong Penubi Standar Akuntansi,

Moh. Nazir, 2011, Metode Penelitian, Cetakan Ketujuh, Ghalia Indonesia, Jakarta

Meleong Lexy j, , 2006. Metode Penelitian Kualitatif Edisi Revisi, Bandung: PT Rosda Karya

Undang Undang no 17 Tabun 2012 tentang perkoperasian Indonesia, Humas Kementerian Koperasi dan UMK 2013

Undang Undang no 28 tabun 2007 tentang Ketentuan Umum dan Tatacara Perpajakan, Direktorat Jendral Pajak, 2008

Lampiran Permen KUKM No. 04/Per/M.KUKM/VII/2012 : Pedoman Umum Akuntansi Koperasi

PPS AK nomor 8 tentang pencabutan PSAK nomor 27 tentang Akuntansi Koperasi, Ikatan Akuntan Indonesia , 2010

Sugianto, 2006. Metode Penelitian Kuantitatif dan R \& D, Bandun: Alfabeta 
Kepatuban Koperasi di Kota Semarang 